\title{
ARTICLE
}

\section{Indirection and the Rhetoric of Tyranny: Carl Schmitt's The Tyranny of Values 1960-1967}

\author{
Samuel Garrett Zeitlin* \\ Corpus Christi College, Cambridge University \\ ${ }^{*}$ Corresponding author. E-mail: sgz21@cam.ac.uk
}

This article situates Carl Schmitt's The Tyranny of Values (1960/1967/1979) within the context of Schmitt's 1940s and 1950s op-ed campaign for full amnesty for Nazi war criminals as well as the context of the Veit Harlan trials and the 1958 Lüth judgment of the German Constitutional Court. The article further examines the revisions to Schmitt's 1967 version of the text in the light of Karl Löwith's criticisms of Schmitt in an article in the Frankfurter Allgemeine Zeitung from 1964. The article argues that The Tyranny of Values is a work of post-Second World War Nazi apologetics, in which Nazi racial theory can be seen being put to polemical ends in the 1960s and 1970s. The article concludes with broader reflections on the relation of Schmitt's The Tyranny of Values to Nazi discourse in the aftermath of the Second World War and the history of Nazism post-1945.

Recent scholarly interpretations of Carl Schmitt's The Tyranny of Values have dwelt upon Schmitt's apparent stance as a defender of legal positivism and formalism against a jurisprudence that grounds itself upon an objective order of values. ${ }^{1}$ Where other recent readers of Schmitt's postwar work have overlooked The Tyranny of Values entirely, ${ }^{2}$ the scholars who attend to The Tyranny of Values have stressed that the Schmitt of the Nazi period had been a stark critic of legal positivism, appealing to a substantive (and racially inflected) constitutional order against the letter of the law as found in the statutes. These scholars stress that

\footnotetext{
${ }^{1}$ Carl Schmitt, Die Tyrannei der Werte (Berlin, 2011; previously published 1960, 1967, 1979). Christoph Schönberger, "Werte als Gefahr für das Recht? Carl Schmitt und die Karlsruher Republik," in Schmitt, Die Tyrannei der Werte (2011), 57-91. As noted by the editors of the 2018 English translation of The Tyranny of Values, "Carl Schmitt published Die Tyrannei der Werte in three separate versions within his lifetime." These versions are, first, in a private printing in 1960, Carl Schmitt, Die Tyrannei der Werte, Überlegungen eines Juristen zur Wert-philosophie (Stuttgart, 1960); second, in an expanded version as a contribution to a Festschrift for Ernst Forsthoff as Carl Schmitt, "Die Tyrannei der Werte," in Säkularisation und Utopie, Ebracher Studien; Ernst Forsthoff zum 65. Geburtstag (Stuttgart, 1967), 37-62; third, a reprinting of the 1967 text as a contribution to a theologically inflected debate on value theory with Eberhard Jüngel and Sepp Schelz in Carl Schmitt, Eberhard Jüngel, and Sepp Schelz, Die Tyrannei der Werte, ed. Sepp Schelz (Hamburg, 1979), 9-43. For further details about the publication of the work in the various editions, see Russell A. Berman and Samuel Garrett Zeitlin, "Note on the Edition and Translation," in Carl Schmitt, The Tyranny of Values and Other Texts, ed. Berman and Zeitlin (Candor, NY, 2018), xiv-xv. See also Alain de Benoist, Carl Schmitt, internationale Bibliographie der Primär- und Sekundärliteratur (Graz, 2010), 71.

${ }^{2}$ See Peter Uwe Hohendahl, Perilous Futures: On Carl Schmitt's Late Writings (Ithaca, 2018), which makes no mention of this late writing by Schmitt.

(C) Cambridge University Press 2020. This is an Open Access article, distributed under the terms of the Creative Commons Attribution licence (http://creativecommons.org/licenses/by/4.0/), which permits unrestricted re-use, distribution, and reproduction in any medium, provided the original work is properly cited.
} 
Schmitt's Tyranny thus represents a postwar volte-face on the question of legal positivism, with Schmitt supporting authoritarian and racialist "values" in jurisprudence before 1945 and critiquing liberal and egalitarian values on the basis of a strategically adopted legal positivism thereafter. ${ }^{3}$

Taking a different, yet complementary, approach to Schmitt's late, privately printed pamphlet, the present article proceeds in five sections. The first section situates The Tyranny of Values within Schmitt's anonymous op-ed campaign for blanket Nazi amnesty, while the second section considers the context of Schmitt's defense of the Nazi propagandist Veit Harlan. The third section examines the 1960 edition of The Tyranny of Values in light of these two contexts. The fourth section considers Carl Schmitt's responses to Karl Löwith in the controversies surrounding Schmitt's pamphlet and Schmitt's alterations to the 1967 edition of the work. The final section concludes with the aim of shedding further light on Carl Schmitt's engagements on behalf of National Socialism (and National Socialists) in the aftermath of the Second World War.

\section{I}

Circulating in multiple journals and newspapers in Germany and in Europe more broadly in the years following the Second World War, there appeared a short, anonymous opinion column advocating blanket amnesty for National Socialists accused of war crimes, crimes against the Jewish people and crimes against humanity, each time in similar form and with a similar argumentative thrust, albeit with variations. Expressing disaffection with de-Nazification, the anonymous author of the column claimed that de-Nazification itself was a manifestation of the "Cold Civil War." Indeed, the writer continued, "The distinguishing mark of this civil war consists in the treatment of the other as criminal, murderer, saboteur and gangster." This anonymous opinion piece claimed that civil wars, of which the "Cold Civil War" was an instance, have historically been resolved only by one of two events. "All civil wars in world history," the writer maintained, "which did not end in the annihilation of the opposing side have ended in an amnesty."

\footnotetext{
${ }^{3}$ Schönberger, "Werte als Gefahr für das Recht?". See also Clara Maier, "Gehegte Demokratie: Zur Idee des Rechtsstaats in Deutschland und Spanien," Mittelweg 36 27/5 (2018), 33-59; Maier, "The Weimar Origins of the West German Rechtsstaat, 1919-1969," Historical Journal 62/4 (2019), 1069-91. For a similar line of argument in earlier scholarship see Ingeborg Maus, Bürgerliche Rechtstheorie und Faschismus: Zur sozialen Funktion und aktuellen Wirkung der Theorie Carl Schmitts, 2nd edn (Munich, 1980; first published 1976), xiv-xv.

${ }^{4}$ See anon. [Carl Schmitt], “Amnestie: Urform des Rechts," Christ und Welt, 10 Nov. 1949, 1-2; anon. [Schmitt], "Amnestie ist die Kraft des Vergessens: Wann werden wir den Bürgerkrieg beenden?", Sonntagsblatt (Hamburg), 15 Jan. 1950. On 21 September 1950, a version appeared in Die Zeit under the byline of "Walter Masuch." The piece was also published twice under Schmitt's own name, once in the Essen-based paper Der Fortschritt and once in the Antwerp-based journal Dietsland-Europa. See Carl Schmitt, "Das Ende des kalten Bürgerkrieges. Im Zirkel der tödlichen Rechthaberei: Amnestie oder die Kraft des Vergessens," Der Fortschritt, 5 Oct. 1951, 1; Schmitt, "Amnestie oder die Kraft des Vergessens," Dietsland-Europa, Oct. 1959, 16-17. Schmitt, "Amnestie oder die Kraft des Vergessens," in Schmitt, Staat, Großraum, Nomos: Arbeiten aus den Jahren 1916-1969, ed. Günter Maschke (Berlin, 1995), 218-21, at 218. In the German original "Gangster" is given in English.

${ }^{5}$ Schmitt, "Amnestie oder die Kraft des Vergessens," in Schmitt, Staat, Großraum, Nomos, 218: "Alle Bürgerkriege der Weltgeschichte, die nicht in der totalen Vernichtung der Gegenseite endeten, haben
} 
Amnesty, on this writer's account, was not a matter of limited scope. In this regard, the concept of amnesty was to be sharply distinguished from pardoning. Amnesty, the author asserted, "means more than a mere pardon on account of a minor offense." ${ }^{6}$ Reiterating the point, the author stressed that amnesty "is not pardoning and it is not alms-giving. He who receives amnesty must also grant it, and he who grants it must know that he receives it as well."7

In contrast to mere pardon, "The word amnesty means forgetting," the author contended, "and not only forgetting but also the strict prohibition [Verbot] against rummaging around in the past and seeking cause for further acts of revenge and further claims of reparation." 8 For this notion of amnesty, the author was keen to grasp for historical precedents and examples. The advocate of Nazi amnesty asserted, "This word amnesty appears for the first time in human language after a terrible thirty years' war, the Peloponnesian War, ${ }^{[9]}$ the war between brothers of the Greek tribes and cities (four hundred years before the Birth of Christ)." Moreover, the author continued, "Cromwell's English Revolution was brought to an end in the year 1660 by means of a law of exculpation and forgetting, an Indemnity and Oblivion Act."10

Seemingly bringing the testimony of English common law against the American and British forces then occupying the defeated Germany, the author noted,

In England today there is still a law on the books from 1495, which has apparently disappeared from the memory of the English, who haven't experienced a civil war in centuries, but which is nonetheless still legally binding and which merits a moment of reflection: after the restoration of normal affairs no one may be punished for the fact that he stood on the wrong side. ${ }^{11}$

mit einer Amnestie geendet." For a rhetorically parallel critique of Versailles in Max Weber's work, see Stefan Eich and Adam Tooze, "Max Weber, Politics, and the Crisis of Historicism," History and Theory 56/2 (2017), 197-215.

${ }^{6}$ Schmitt, "Amnestie oder die Kraft des Vergessens," in Schmitt, Staat, Großraum, Nomos, 219: "Amnestie bedeutet also mehr, als eine bloße Begnadigung wegen kleiner Vergehen."

${ }^{7}$ Ibid., 219: "Sie ist keine Begnadigung und kein Almosen. Wer Amnestie nimmt, muß sie auch geben, und wer sie gibt, muß wissen, daß er sie auch nimmt."

${ }^{8}$ Ibid., 218: "Das Wort Amnestie bedeutet Vergessen, und nicht nur Vergessen, sondern auch das strenge Verbot, in der Vergangenheit herumzuwühlen und dort Anlaß zu weiteren Racheakten und weiteren Entschädigungsansprüchen zu suchen.” For an account of alternate views of forgiving (that do not entail forgetting) in the aftermath of the Second World War see Emma Stone Mackinnon, "Promise-Making and the History of Human Rights: Reading Arendt with Danto," Humanity 9/2 (2018), 193-217, at 203.

${ }^{9}$ Schmitt also refers to the Peloponnesian War as a thirty years' war in his Dialogue on New Space (19558). See Carl Schmitt, Dialogues on Power and Space, trans. S. G. Zeitlin, ed. Andreas Kalyvas and Federico Finchelstein (Cambridge, 2015), 58.

${ }^{10}$ Schmitt, “Amnestie oder die Kraft des Vergessens," in Schmitt, Staat, Großraum, Nomos, 218. The Act of Indemnity and Oblivion meant, with certain stated exceptions, to legally efface the prosecution (and even mention) of crimes committed during the Interregnum and the English Civil Wars. On the Act of Indemnity and Oblivion see Ronald Hutton, The Restoration: A Political and Religious History of England and Wales 1658-1667 (Oxford, 1986), 132-8, 162-6. Hutton writes that for prohibiting speech about deeds and acts committed during the Interregnum "the act was an almost complete formal success in that there seems to have been only one prosecution under it (in Dorset in 1663) for berating somebody for his wartime record.” Ibid., 135. In effect, by anonymously advocating for oblivion, Schmitt is arguing for the criminalization of discussion of atrocities and crimes committed under National Socialism.

${ }^{11}$ Schmitt, "Amnestie oder die Kraft des Vergessens," in Schmitt, Staat, Großraum, Nomos, 218-19. 
In stressing that amnesty means oblivion and forgetting, the anonymous advocate for Nazi amnesty was pushing not merely for the nullification, pardoning and nonpersecution of the atrocities of National Socialism. Rather, the writer was arguing that such atrocities must be forgotten. "Amnesty is more than a discharging of the persecutorial apparatus of the state," the author wrote. "It is a reciprocal act of forgetting."12 Against those who would initiate or heed the call never to forget, this anonymous writer would assert the opposite.

This short, anonymously penned column finished with a hortatory clause, rounding off perhaps with a kind of prayer. "At the very least," the writer offered in closing, "let us sustain this recollection of a remnant of holy right, that therewith the final and only means of ending the Cold Civil War in a humane way may not be forgotten!"13

The author of this missive, reprinted multiple times in various German and European newspapers and journals in the years 1949-1959, was none other than the Nazi jurist and former section head of the Association of National Socialistic German Jurists, Carl Schmitt. In the three decades following his release from solitary confinement at Nuremberg in 1947, Schmitt would repeatedly reprise the theme of the absence of German guilt for the atrocities of the Second World War, not least in his polemical pamphlet The Tyranny of Values, insisting that any ex post criminal convictions for Nazi atrocities that were juridically permissible when committed were an aberration. ${ }^{14}$

For background to this rhetoric of National Socialist exculpation, and to the circumstances which would inflect it in Schmitt's privately printed pamphlet The Tyranny of Values upon its first appearance a decade later, some historical details and their reflection in postwar German jurisprudence merit consideration.

\section{Background: Veit Harlan and the Lüth judgment}

At the end of Veit Harlan's 1940 film Jud Süß $\beta$, the film's titular protagonist, depicted as a bearded and mustachioed Jewish financial adviser, and an erstwhile torturer, rapist and murderer in addition, is narrowly encaged before being hung from the high gallows of southern Germany in an execution preceding the expulsion of the Jews of Württemberg from its domains. ${ }^{15}$ While putatively based on the

\footnotetext{
${ }^{12}$ Ibid., 219.

${ }^{13}$ Ibid.

${ }^{14}$ For Schmitt as an exculpatory rhetorician for National Socialist crimes see Victoria Kahn, The Future of Illusion: Political Theology and Early Modern Texts (Chicago, 2014), chap. 1; and Kahn, "Hamlet or Hecuba: Carl Schmitt's Decision," Representations 83/1 (2003), 67-96. See also Peter Uwe Hohendahl, Perilous Futures: On Carl Schmitt's Late Writings (Ithaca, 2018), 19-59; Samuel Garrett Zeitlin, "Interpretation and Critique: Jacob Taubes, Julien Freund, and the Interpretation of Hobbes," Telos 181 (2017), 9-39, at 37 n. 89. Cf. Carl Schmitt, Die Tyrannei der Werte (2011), 52.

${ }^{15}$ The film programs for $J u d$ Süß stressed the extraordinary height of the gallows upon which Süß was hanged: "Ihm wurde der Prozeß gemacht, die Richter verurteilten ihm zum Tode, und die Zunft der Schmiede baute einen Galgen eigens für den Juden, höher als alle Galgen zuvor." The content of the film programs for Jud Süß are reprinted in "Filmographie, Filmhandlungen und Bilder aus den Programmheften zum 'Jud Süß'-Film," in Thomas Henne and Arne Riedlinger, eds., Das Lüth-Urteil aus (rechts-)historischer Sicht (Berlin, 2005), 401-8, at 404. Compare Matthew Specter, Habermas: An Intellectual Biography (Cambridge, 2010), 74: "The Lüth-Harlan decision of 1958 was six and a half
} 
eighteenth-century life of Joseph Süss Oppenheimer, Harlan's film, financially underwritten by Goebbels and the Nazi Propaganda Ministry, fictionalized to propagandistic and anti-Jewish ends. In the crowd scenes for the film, Harlan infamously deployed extras from the Jewish ghettos of Prague and Lublin, then under Nazi occupation. ${ }^{16}$ Not for the last time, in Harlan's film Jews were conscripted into the construction of the propaganda which was to be used against them. Harlan's Hetzfilm stirring moralized panic and hatred against the Jewish people received wide publicity and play throughout a National Socialist Germany at the pinnacle of its military and imperial power upon and after its release in September 1940, not least in formal showings for SS officers, National Socialist police and concentration camp guards. ${ }^{17}$ For his work as author of the screenplay and director of anti-Jewish propaganda films, Harlan was charged with crimes against humanity and criminal libel in British-occupied Hamburg in the aftermath of the Second World War, yet was twice juridically cleared, ultimately on the ground of Harlan's claim that in the circumstances he could not have acted otherwise. ${ }^{18}$

Following the Second World War, Veit Harlan returned to filmmaking. Less than a decade after Jud Sü $\beta$ played to acclaim in German cinemas and before audiences throughout German-occupied Europe, Harlan had been juridically cleared of culpability by the order in place in the aftermath of the Second World War. By 1950, Veit Harlan's latest cinematic offerings were again given prominent place in the festive Week of German Film sponsored at state expense in Hamburg in 1950. The law courts record the sequence of events as follows. At the opening of the Week of German Film in Hamburg in September 1950, the director of the Hamburg Senate and State Press Office of the Free Hanseatic City of Hamburg, Erich Lüth, declared the following in his capacity as director of the Hamburg Press Club in a discussion with film distributors and film producers:

After the German film industry destroyed its moral reputation in the Third Reich, one man is in any case least fit of all to restore its reputation: the screenwriter and director of the film Jud Süß! May we spare ourselves further unforeseeable shame before the entire world, which may arise, should one seek to set him up as a representative of German film. His acquittal in Hamburg was only formal. The grounding of the decision was a moral damnation. Here we require of the distributors and theater possessors a stance, which doesn't come cheap, which should cost one something: character. And this character

years in the making. The case involved a filmmaker popular during the Third Reich, Veit Harlan (18991964), who had directed the notoriously anti-Semitic Jud Süß (The Jew Süss, 1940). The film fictionalizes the eighteenth-century life of Joseph Süss-Oppenheimer (1698-1738), a Jewish financial advisor and tax collector for the Duke of Württemberg. It depicts Süss as a rapist and torturer of a Christian woman who was brought to justice by an Aryan-Christian German community. Joseph Goebbels strongly supported the making of the film, which was hugely popular in the Third Reich."

${ }^{16}$ On Harlan's use of extras in his film composition see the 2008 documentary film directed by Felix Moeller, Harlan im Schatten von Jud Süß.

${ }^{17}$ For the post-Second World War criminal charges against Harlan see "Strafverfahren gegen Veit Harlan," in Henne and Riedlinger, Das Lüth-Urteil, 411-18.

${ }^{18}$ For the text of the two verdicts of acquittal for Harlan see "Der erste Freispruch Harlans vom 23. April 1949" and "Der zweite Freispruch Harlans vom 29. April 1950," in Henne and Riedlinger, Das Lüth-Urteil, 419-34, 445-56. 
I wish for German film. If it shows it and demonstrates the proof via fantasia, optical cleverness and sureness of handicraft then it deserves every help and then it will attain something which it needs to live: success with a German as with an international public. ${ }^{19}$

When lawyers for Harlan's production company protested against Lüth's declaration against Harlan, Lüth responded in writing in an open letter which he made public via the Hamburg Press Club: ${ }^{20}$

The court [Schwurgericht] hardly refuted that Veit Harlan was for a great period during the time of the Hitler-Reich the "Number 1 Nazi film director" and via his film Jud Süß one of the most important exponents of the Nazis' murderous Jew-baiting [mörderische Judenhetze]. At home and abroad there may be business people who are not disturbed by Harlan's comeback. Germany's esteem in the world, however, must not be ruined anew by robust moneymakers [robusten Geldverdiener] ... For all these reasons, it is not only the right of responsible Germans, but even their duty in the battle against this unworthy representative of German film, to go beyond protest and hold themselves ready for the boycott! ${ }^{21}$

On the basis of this boycott declaration that denounced Harlan as a criminal and a "most important exponent of murderous Jew-baiting," Harlan's producers sued Lüth both for misprision (Unterlassung) and for making appeals for a morally reprehensible boycott (sittenwidriger Boykottaufruf), because, the lawyers claimed, the calls for boycott were based upon the factually inaccurate claim that Harlan was a criminal. Harlan's producers argued that Lüth's call for a boycott of Harlan's work violated Section 826 of the Bürgerliches Gesetzbuch (BGB), the German Civil Code, since Harlan had been cleared of all criminal charges. That section of the German Civil Code obliges that whoever damages another intentionally in a manner proscribed by law and against good morals is obliged to compensate the damages. ${ }^{22}$ The Hamburg courts decided the question relying wholly on the Civil Code. The lawyers for Harlan's producers argued that Lüth knew that Harlan had been cleared of criminal charges and thus aimed intentionally to damage Harlan by calling for a boycott on the basis of Harlan's activities in the service of the Third Reich. Harlan's producers won the case in the civil court, ${ }^{23}$ with the result that Lüth was forbidden

\footnotetext{
19"'Das Lüth-Urteil des Bundesverfassungsgerichts (BVerfGE 7, 198 ff.)," in Henne and Riedlinger, Das Lüth-Urteil, 543-66, at 544 (199 of the original 1958 decision).

${ }^{20}$ Ibid. (200 of the original 1958 decision).

${ }^{21}$ Ibid.

${ }^{22}$ The text of section 826 of the BGB reads, "\$ 826 Sittenwidrige vorsätzliche Schädigung. Wer in einer gegen die guten Sitten verstoßenden Weise einem anderen vorsätzlich Schaden zufügt, ist dem anderen zum Ersatz des Schadens verpflichtet”/“ $\$ 826$ Morally repellent deliberate damaging. Whoever intentionally damages another against good morals is duty-bound to compensate the other for the damages."

${ }^{23}$ Dieter Grimm, "Die Karriere eines Boykottaufrufs: Wie ein Drehbuchautor Rechtsgeschichte machte. Zum 50. Geburtstag des Bundesverfassungsgerichts," Die Zeit 40 (2001), 11: "Filmproduzent und Filmverleiher klagten darauf gegen Lüth vor den Zivilgerichten. Diese sahen in Lüths Äußerung einen sittenwidrigen Boykottaufruf und verboten ihm, gestützt auf Paragraf 826 des Bürgerlichen Gesetzbuchs, die Aufforderung"/"The film producer and film distributor thereupon sued Lüth before the civil courts. These
} 
by court order to call for the German public not to see the film and to call for theater owners and film distributors not to show it. ${ }^{24}$

Lüth appealed this civil judgment to the superior court in the state of Hamburg and simultaneously appealed to the Federal Constitutional Court, arguing that he was expressing political and moral critique of Harlan and that this was protected under Article 5 of the German Basic Law, which grants express protection to freedom of expression. ${ }^{25}$ Where the civil court had aimed to test whether his claims of Harlan's moral reprehensibility were true, Lüth and his lawyers maintained that what mattered was whether these claims were legally permissible and that they were indeed permissible as constitutionally protected speech.

In the Lüth case, the contested constitutional question hinged on whether basic rights (such as protections for freedom of expression) applied merely vertically (to be asserted by the individual citizen against the state) or whether rights protections applied also horizontally (to be asserted by citizens against other citizens) - in other words, whether constitutional protections to freedom of speech applied only in public law (vertically) or also in civil and private law (horizontally). If constitutional rights protections applied only vertically (against the state and its agents), as the lawyers representing Harlan and his film producers contended, then Harlan and the film production companies might assert damages for misprision against Lüth and forbid his calls for boycott. On the contrary, if Lüth was speaking in his capacity as an individual citizen and if constitutional protections against interference with freedom of expression might be claimed not only against the state but also against one's fellow citizens, then Lüth might assert his right to call Veit Harlan a moral reprobate and advocate a boycott of Harlan's work on the basis of the latter's past as a Nazi propagandist irrespective of whether or not Harlan had been convicted of a crime. In this case, the Hamburg state courts decided the matter in the first manner; on appeal, the German Federal Constitutional Court decided the matter in the second.

The jurisprudence of the Federal Republic prior to the decision had held that basic rights (like freedom of expression) applied only vertically (against the state) and not against fellow citizens in private law. ${ }^{26}$ The judgment of the Federal Constitutional Court in the Lüth case changed this, and expanded the applicability

saw in Lüth's expression a morally repellent call for a boycott and forbade him, based upon paragraph 826 of the BGB [Civil Code], the call [for the boycott]." See further Specter, Habermas, 74: "Lüth was deemed to have violated Article 826 of the Civil Code, which read, "Whoever causes damage to another person intentionally and in a manner offensive to good morals is obligated to compensate the other person for the damage."”

24"Das Lüth-Urteil des Bundesverfassungsgerichts (BVerfGE 7, 198 ff.)," in Henne and Riedlinger, Das Lüth-Urteil, 543-66, at 545 (200 of the original 1958 decision).

${ }^{25}$ Ibid. (202 of the original 1958 decision).

${ }^{26}$ The former justice of the Federal Constitutional Court Dieter Grimm explains the pre-Lüth state of German jurisprudence as follows: "Das wird erst deutlich, wenn man weiß, was vor Lüth galt. Daran hatten sich nämlich die Zivilgerichte gehalten. Ihre Entscheidung fiel keineswegs aus dem Rahmen: Ein Rechtsstreit zwischen Privatleuten wird nach Privatrecht entschieden, und im Privatrecht spielen Grundrechte keine Rolle. Mit Grundrechten kann sich der Einzelne gegen Eingriffe des Staates verteidigen"/"This first becomes clear, if one knows what held before Lüth. The civil courts had held themselves to this. Their decision in no way fell outside the frame: a legal conflict between private persons is decided according to private law, and in private law the basic rights play no role. With basic rights, the individual 
of basic rights so that they applied both vertically and horizontally, while holding that Lüth called for the boycott in his private, rather than public, capacity. The expansion of the applicability of basic rights, like freedom of opinion and expression, into the domain of private law was effected by the Constitutional Court in the Lüth case via value-theoretical argumentation. ${ }^{27}$ While stressing that the basic rights in the German Basic Law were in the first instance rights of defense (Abwehrrechte) of the individual against the state, the deciding opinion in the Lüth case argued, "It is equally correct that the Basic Law, which does not desire to be a value-neutral order, has also erected an objective order of values [objektive Wertordnung] in its passage on the basic rights and that precisely herein a principled strengthening of the basic rights comes to expression. This value system," the Court continued, "which finds its midpoint within the social community of the freely developing human personality and its dignity, must hold as a constitutional-legal fundamental decision for all domains of law"-from legislation to administration to civil law, in the domains of both public and private law. ${ }^{28} \mathrm{On}$ the account of the Federal Constitutional Court, via the "objective order of values" in the Basic Law, the right to freedom of expression permeates into civil law. The court laid out a general doctrine of interpreting each part of the law (including private law) in light of the objective order of values enshrined in the Basic Law. In its decision, the court first set out the general interpretive doctrine in order to overturn the misprision (Unterlassung) charges against Erich Lüth. Where the lower legal instances, such as the civil courts in Hamburg, had decided the case solely on the basis of the Bürgerliche Gesetzbuch (the Civil Code), the Federal Constitutional Court, in a historical first, applied the rights of the Basic Law to the case: without the application of the "objective order of values" enshrined in the Basic Law to the entirety of German law, the charges of misprision and boycotting contrary to good morals would not have been overturned. ${ }^{29}$ By expanding the basic right of freedom of expression into the domain of private law, on the basis of the "objective order of values" present in the basic rights of the Basic Law, the court allowed that Lüth's right of freedom of expression trumped the charge of

can defend himself against the assaults of the state." Grimm, "Die Karriere eines Boykottaufrufs." The decision made it clear that basic rights are applicable to relations between citizens.

${ }^{27}$ In the first decade of the Federal Republic, Jan-Werner Müller notes, "Guarding the constitution became a preoccupation-even if views of who should do the guarding diverged widely between a strong president, the courts and even the unions. The issue seemed settled when the Constitutional Court emerged as the widely accepted occupant of this role after a number of landmark decisions in the late 1950s. In particular, the Court handed down a seminal judgement in the so-called Lüth case of 1958. There the judges defended the right to free speech of Hamburg's director of information, who had called for a boycott of the film Immortal Lover by Veit Harlan. Harlan had been popular with Goebbels and had made antisemitic films such as the infamous Jud Süss. The Court used the case to reinterpret basic rights, which had so far been understood exclusively in terms of defence mechanisms against the state, as principles which permeated the entire legal order." Jan-Werner Müller, A Dangerous Mind: Carl Schmitt in Post-war European Thought (New Haven, 2003), 63-4.

28" Das Lüth-Urteil des Bundesverfassungsgerichts (BVerfGE 7, 198 ff.)," in Henne and Riedlinger, Das Lüth-Urteil, 543-66, at 548 (205 of the original 1958 decision): "Ebenso richtig ist aber, daß das Grundgesetz, das keine wertneutrale Ordnung sein will, in seinem Grundrechtsabschnitt auch eine objektive Wertordnung aufgerichtet hat."

${ }^{29}$ The author is thankful to Joshua Smeltzer for helpful correspondence on this point. 
misprision and prohibition of his boycott on moral grounds, and the court thereby asserted that Lüth's constitutional rights overrode the private rights of Harlan and his producers and distributors. The civil legal judgments against Lüth were dissolved and with them the claim that Lüth had committed misprision against Harlan in proclaiming him "one of the most important exponents of murderous Jew-baiting by the Nazis."

\section{Carl Schmitt and the Lüth decision: The Tyranny of Values}

From the early 1950s onward, Carl Schmitt expressed a keen interest in the Lüth case. In a letter to his former doctoral student Ernst Forsthoff dated 3 September 1953, he lamented the "persecutions driven ever further" of former Nazi officials and collaborators. ${ }^{30}$ The example Schmitt marshaled was that of "Karl Korn" initiating a "kind of Veit-Harlan affair against Heidegger" in the pages of the Frankfurter Allgemeine Zeitung. ${ }^{31}$ In his personal files and records, Schmitt assembled materials of calls to prohibit, ban and boycott his own public speech and his ability to assume a platform within a university setting, but also press materials and newspaper clippings related to Harlan's case and the calls for boycott of the Nazi cineaste's postwar films. ${ }^{32}$ As the historian Kai Burkhardt observed,

\footnotetext{
${ }^{30}$ Letter of Carl Schmitt to Ernst Forsthoff dated 3 Sept. 1953, in Briefwechsel Ernst Forsthoff-Carl Schmitt (1926-1974), ed. Dorothee Mußgnug, Reinhard Mußgnug and Angela Reinthal, with Gerd Giesler and Jürgen Tröger (Berlin, 2007), Letter 62, 97: "Nach den immer weiter betriebenen Verfolgungen und dem ungenierten Triumph privater Rachsucht und unlautersten Wettbewerbs, traf mich eine solche mutige Anerkennung so tief, dass sie mir das Bild von meinem Beruf und meinem Stande wieder erträglich gemacht hat."

${ }^{31}$ Ibid.: "Was Karl Korn von der FAZ getrieben hat, eine Art Veit-Harlan-Sache gegen Heidegger in Gang zu bringen, weiss ich nicht. Ich traf ihn Mitte August, zwei Tage vor seinem Aufsatz 'Warum schweigt Heidegger'; er liess sich aber nichts merken. Rothacker, der Lehrer des Heldenjünglings Habermas, gehört doch wahrhaftig in erster Linie zu den Jasagern von 1933. Wie sonderbar ist das alles!"/"What drove Karl Korn of the Frankfurter Allgemeine Zeitung to bring about a kind of Veit-Harlan affair against Heidegger, I don't know. I met him in mid-August, two days before his article 'Why Is Heidegger Silent' appeared; but he didn't mention a thing. Rothacker, the teacher of the heroic youth Habermas, nonetheless truly belongs in the first instance among the yea-sayers of 1933. How odd all this is!" The editors of the SchmittForsthoff correspondence introduce the following note on the Lüth case in clarification of this passage: "The actor Veit Harlan (1899-1964) was criticized and accused after 1945 above all on account of his work as author of the screenplay and director of the films Jud Süß and Kolberg. When the director of the Hamburg Senate, Erich Lüth (1902-1989) called for a boycott of Harlan's films produced after the war (20 September 1950), the production company sued Lüth for misprision [Unterlassung] and pushed through at the level of the State Supreme Court [of Hamburg]. Lüth raised constitutional issues. The Federal Constitutional Court dissolved the judgment of the State Supreme Court (the so-called Lüth-Urteil of 15 January 1958, BVerfGE 7, S. 198-230).” Dorothee Mußgnug, Reinhard Mußgnug and Angela Reinthal, with Gerd Giesler and Jürgen Tröger, "Kommentar," in Briefwechsel Ernst ForsthoffCarl Schmitt, 399. There is surprisingly no mention of Harlan in the study of Raphael Gross, Carl Schmitt und die Juden: Eine deutsche Rechtslehre, 2nd rev. edn, (Frankfurt, 2005; first published 2000). See also Raphael Gross, Carl Schmitt and the Jews: The "Jewish Question," the Holocaust, and German Legal Theory, tr. Joel Golb (Madison, 2007).

${ }^{32}$ Dirk van Laak, Gespräche in der Sicherheit des Schweigens: Carl Schmitt in der politischen Geistesgeschichte der frühen Bundesrepublik, 2nd edn (Berlin, 2002; first published 1993]), 143 n. 44: "Diese Sicht auf repräsentative, stellvertretende 'Fälle' entsprach übrigens Schmitts eigener Wahrnehmung, und er sammelte nicht nur die Berichte zur eigenen Person, sondern auch Stellungnahmen zu Veit Harlan, Werner Krauss, Kurt Ziesel, Hans Globke etc. (vgl. das Notizheft HSTAD RW 265-61, Mat.-Nr. 15).”
} 
considering Schmitt's stance toward the Lüth case, "In this case, Schmitt stood on Harlan's side." ${ }^{33}$

Following the 15 January 1958 decision of the Federal Constitutional Court for Lüth and against Harlan, Schmitt's language in his postwar diary Glossarium (running in the expanded edition to the end of 1958) turned increasingly to a concern with things being transformed into values (Verwertung). ${ }^{34}$ These concerns would be reiterated in Schmitt's lecture on "The Tyranny of Values" delivered in Ebrach later in the following year. As Schmitt himself observes in the 1967 introduction to the second edition of his text, The Tyranny of Values emerged out of this lecture, delivered in October of 1959.

Invited to speak at the restricted private seminar in Ebrach organized by his former doctoral student Ernst Forsthoff (like Schmitt, an early supporter of National Socialism and author of the 1933 Nazi pamphlet Der totale Staat), ${ }^{35}$ Schmitt observed that his remarks in the published text "pertain to a discussion on 'Virtue and Value in State Theory,' which in connection with a presentation by Professor Ernst Forsthoff took place in Ebrach on 23 October 1959." ${ }^{36}$ Having been delivered as a lecture, the text of The Tyranny of Values was, on Schmitt's account, "worked over and made available to the participants of the conference and some friends as a private printing of roughly 16 pages in an edition of $200 \mathrm{cop}$ ies." ${ }^{37}$ In line with the setting addressing the participants of Forsthoff's

\footnotetext{
${ }^{33}$ Kai Burkhardt, "Einführung," in Burkhardt, ed., Carl Schmitt und die Öffentlichkeit: Briefwechsel mit Journalisten, Publizisten und Verlegern aus den Jahren 1923 bis 1983 (Berlin, 2013), 11-50, at 28 n. 49.

${ }^{34}$ See the entry dated 21 Sept. 1958 in Carl Schmitt, Glossarium: Aufzeichnungen aus den Jahren 1947 bis 1958, ed. Gerd Giesler and Martin Tielke (Berlin, 2015), 373: "Korfu Legende und ihrer Verwertung für Wiedergutmachungsforderungen."

${ }^{35}$ Ernst Forsthoff (1902-74) was an administrative and constitutional lawyer, a legal academic, and an early proponent of German National Socialism. One of Schmitt's doctoral students at Bonn, Forsthoff was a member of the National Socialist Party and a professor of law at numerous universities, including Frankfurt am Main, Hamburg, Vienna and Heidelberg. Forsthoff was the author of the 1933 pamphlet Der totale Staat (The Total State), advancing an anti-Jewish and Hitlerian politics. Of this pamphlet Peter Caldwell writes, "The pamphlet was one of many of the time that greeted the National Socialist revolution and sought to shape it, in this case with an eye toward Schmitt's model authoritarianism. It acclaimed the end of democracy, welcomed authoritarian rule, and embraced anti-Semitism ... With good reason, those who sought to ban Forsthoff from the academy after 1945 pointed to this work. Its anti-Semitism was stated baldly; it proclaimed, for example, that the essentially different (artverschieden) Jew had become, regardless of his subjective attitude toward Germany, an enemy that had to be rendered harmless (unschädlich)." Peter C. Caldwell, "Ernst Forsthoff in Frankfurt: Political Mobilization and the Abandonment of Scholarly Responsibility," in Moritz Epple, Johannes Fried, Raphael Gross and Janus Gudian, eds., "Politisierung der Wissenschaft": Jüdische Wissenschaftler und ihre Gegner an der Universität Frankfurt am Main vor und nach 1933 (Göttingen, 2016), 249-83, at 269. Unlike Schmitt, who was permanently banned from university teaching following the Second World War, Forsthoff resumed his professorship at the University of Heidelberg during the 1950s and 1960s. Forsthoff was the editor of the first two Festschrifts honoring Schmitt on his seventieth and eightieth birthdays and the dedicatee of Schmitt's Theory of the Partisan (1963). The second, 1967, edition of The Tyranny of Values was Schmitt's contribution printed in the 1967 Festschrift for Forsthoff, Säkularisation und Utopie, dedicated to Forsthoff in celebration of his sixty-fifth birthday.

${ }^{36}$ Carl Schmitt, "Die Tyrannei der Werte," in Säkularisation und Utopie: Ebracher Studien. Ernst Forsthoff zum 65. Geburtstag (Stuttgart, Berlin, Cologne and Mainz, 1967), 37-62, at 37; Schmitt, Die Tyrannei der Werte (2011), 9.

${ }^{37}$ Schmitt, Die Tyrannei der Werte (1967), 50; Schmitt, Die Tyrannei der Werte (2011), 32. In his 2009 biography of Schmitt, Aufstieg und Fall, Mehring cites a lower figure of 150 copies for the print run of the
} 
invitation-only seminar (which, in addition to Forsthoff and his students, included both Schmitt's fellow jurists and several of his former comrades in National Socialism), Schmitt's Tyranny of Values pursued a critique of the jurisprudential basis of the judgment in the Lüth case and with it an indirect defense of Veit Harlan against charges of criminality and boycotts related to the crimes of Nazism.

Schmitt's defense of Veit Harlan in The Tyranny of Values pursues a highly indirect rhetorical strategy. In the pamphlet, Schmitt attacks the philosophic fundament of value theory in order to undermine the very notion of an "objective order of values," 38 the basis upon which the Federal Constitutional Court had expanded the constitutional protections of freedom of speech in the Basic Law into private law, in order to overturn the misprision charges against Lüth and to rule against Harlan in the boycott case.

The Tyranny of Values is marked in its subtitle as the "reflections of a jurist" 39 with the accompanying ambiguity that a jurist may be a mere citizen, a legal scholar, or a high state functionary. In Schmitt's pamphlet the reflections of a jurist are juxtaposed against those who would wield value theory and philosophy in their jurisprudence, ${ }^{40}$ with the implication that a jurist, rather than a freethinker or philosopher, would stick with jus and jura. With or without great subtlety, Schmitt is situating himself as more of a jurist than those seated upon the Federal Constitutional Court in temporal proximity to the original publication of his pamphlet.

Schmitt opens his pamphlet with a set of sharply pointed questions. "What are values?" Schmitt asks, and, further, what does a value philosophy signify? What does a value philosophy mean $?^{41}$ Schmitt begins his approach by writing on how values are ordinarily spoken about. Values, Schmitt stresses, are distinguished from things which lack value. ${ }^{42}$ But crucially, Schmitt is quick to point out, values are usually ascribed not to persons, but to things-people are spoken of as having dignity; things are spoken of as having value. ${ }^{43}$

1960 edition of The Tyranny of Values, but does not give a citation or source for this lower figure. See Reinhard Mehring, Carl Schmitt: Aufstieg und Fall (Munich, 2009), 524.

${ }^{38}$ For the Lüth judgment of the Federal Constitutional Court as the polemical target in Schmitt's Tyranny of Values, Jan-Werner Müller notes, "Increasingly, however, the Court interpreted basic rights and norms as being based on an objective order-and ranking-of values. The notion of an objective order of values, which affected all areas of law-including private law-had also been the crucial innovation in the Lüth case. This form of jurisprudence was often explicitly based on Smend's antipositivist communitarianism, and in particular the idea of social integration through a concrete symbolic ordering of values expressed in the constitution. Schmitt vociferously opposed the philosophy of values and repeatedly condemned what, following Hartmann, he called the 'tyanny of values'”. Müller, A Dangerous Mind, 71. See also Mehring, Aufstieg und Fall, 520.

${ }^{39}$ Schmitt, Die Tyrannei der Werte (1960), 1.

${ }^{40}$ For Schmitt's perjorative understanding of philosophy extending beyond The Tyranny of Values to Schmitt's work as a whole, not least in his postwar diaries, see Heinrich Meier, "Der Philosoph als Feind: Zu Carl Schmitts 'Glossarium'," in Meier, Carl Schmitt, Leo Strauss und "Der Begriff des Politischen": Zu einem Dialog unter Abwesenden, 3rd edn (Stuttgart, 2013; first published 1988), 141-52.

${ }^{41}$ Schmitt, Die Tyrannei der Werte (1960), 3.

${ }^{42}$ Ibid., 3 .

${ }^{43}$ Ibid., 3. In Schmitt's view, values are not quite properly ascribed to persons or, by extension, to relations between persons- to do so, indeed, has something undignified about it. The point had been made earlier in the work of Kant, in the Grundlegung zur Metaphysik der Sitten. 
Continuing to elucidate what he takes to be the grammar of the concept of value, Schmitt notes that the grammar of value implies the nonexistence of value. Values, Schmitt says, are said to hold rather than to be or exist: "Value is not, rather it holds." ${ }^{44}$ The way in which value is spoken about, on this view, points to something dubious about value itself. "The validity admittedly implies," Schmitt continues, "as we shall yet see more closely, an all-the-stronger compulsion toward realization. Value precisely lusts after actualization. It isn't real, but directed toward realization and longs for enforcement and implementation." 45 Three paragraphs into his pamphlet, Schmitt has already asserted not only that the term "value" is improperly applied to persons (and to relations between them) but also that value, the conceptual basis for the decision in the Lüth judgment, isn't real ("Es ist nicht wirklich")value, properly understood, doesn't even exist. If values do not exist, then appeals to values simply express someone's preferences or wishes. Thus the appeal to values is simply a way to impose one's own preferences on others. On this argument, the justices of the Federal Constitutional Court rendered their decision for Lüth and against Harlan on the ground of an unreality, on the basis of nothing.

In the pamphlet, Schmitt turns from critically elucidating the grammar of value, in which he had emphasized the unreality of value terms, to sketching a genealogy of value in the history of ideas in the nineteenth and twentieth centuries. Schmitt begins this genealogy with an extensive citation from Heidegger's 1950 collection Holzwege, in which Heidegger claims that the popularization of the language of value begins with the thought of Friedrich Nietzsche, from which point in the history of thought, "Value and the valuable become the positivistic ersatz for the metaphysical." 46 Following this protracted quotation, Schmitt quickly affirms Heidegger's assessment in his own voice. "With these sentences," Schmitt writes, "Martin Heidegger aptly defined and rightly placed the ancestry and situation of value philosophy in the history of philosophy." ${ }^{47}$ Value philosophy, on this picture, represents a nineteenthcentury attempt of the humanities and human sciences to respond to the challenge of a value-free empirical science which sought causal laws that seemed to impinge upon human "religious-ethical-juristic responsibility." "Value philosophy,"

\footnotetext{
${ }^{44}$ Ibid., 3, italics original.

${ }^{45}$ Ibid., 3. On the question of the enforcement of values in Schmitt's understanding, Jan-Werner Müller notes, "The logic of values, he claimed, carried an 'immanent aggressiveness'. It was not enough for values to be posited, their validity also had to be enforced. In Schmitt's untranslatable German wordplay: Setzung, the positing of values, implied their Durchsetzung, their, if necessary, violent enforcement." Müller, $A$ Dangerous Mind, 71.

${ }^{46}$ Schmitt, Die Tyrannei der Werte (1960), 5: "Der Wert und das Werthafte wird zum positivistischen Ersatz für das Metaphysische." Schmitt's quotation of Heidegger is italicized in the German original. Compare Martin Heidegger, Holzwege (Frankfurt am Main, 1950), 193-4, 209-10. For the importance of this reference to Schmitt's argument in The Tyranny of Values see Mehring, Aufstieg und Fall, 520.

${ }^{47}$ Schmitt, Die Tyrannei der Werte (1960), 5: "Herkunft und philosophie-geschichtliche Lage der Wert-Philosophie sind mit diesen Sätzen Martin Heideggers treffend bestimmt und richtig verortet ... Diesen Versuch kann man wohl als positivistischen Ersatz für das Metaphysische bezeichnen." Compare, in another context, Christian Linder, Der Bahnhof von Finnentrop: Eine Reise ins Carl Schmitt Land (Berlin, 2008), 12: "Man merkt diesen Sätzen, die nicht von Carl Schmitt, sondern von Martin Heidegger stammen, die Schmitt aber ebenso gut hätte schreiben können, ihre Herkunft aus einer alten Zeit an"/"One recognizes in these sentences, which do not stem from Schmitt, but rather from Martin Heidegger, but which Schmitt could equally have written, their descent from an elder time."
} 
Schmitt maintained, "answered this challenge, in setting against the realm of an only causally defined being a realm of values, as a realm of ideal validity. It was an attempt to maintain the human as a free, responsible essence, not, namely, in being [Sein], but at least in the holding of that which one called value." 48

Value is thus figured, by both Schmitt and Schmitt's Heidegger, as a term which attempts to substitute for virtue, dignity, piety and sanctity while trying to save human responsibility within a broader secularization narrative of the history of philosophy and ethical language. It is not wholly clear, on Schmitt's presentation, whether he regards the attempt (Versuch) of value philosophy to have been a successful one. Crucially, on this presentation, value is ersatz metaphysics-value is not constitutive of the strict reading of the letter of the law as written.

From deploying Heidegger's assessment of value as ersatz metaphysics, Schmitt turns to Max Weber's view of value. Value theory, Schmitt is keen to observe, is a matter of setting values, laying them down, and making them hold. Setting down values poses the question of who is to set them down-a human, a god, a king, a legislature, a court or a constitutional assembly of the people as a whole? "Who is it now," Schmitt asks, "who sets values here?" ${ }^{49}$ Schmitt, who knew and studied with Weber at the end of the latter's academic career, answers his own question with an initially laudatory account of the thought of his former teacher: "In Max Weber we find the clearest and to that extent also the most honest answers to these questions. According to him it is the human individual, who in full, pure subjective freedom of decision sets values. In this way it avoids the absolute value-freedom of scientific positivism and sets it free, that is: subjective worldview against scientific positivism." ${ }^{\text {" }}$

Yet, for Schmitt, Weber's subjective account of values situated within potentially incommensurable worldviews has a fatal and potentially frightening flip side. Drawing attention to Weber's analysis of "the battle of value orders" (Der Kampf der Wertordnungen), ${ }^{51}$ Schmitt writes, "The purely subjective freedom of value setting, however, leads to an eternal battle of values and of worldviews, a war of all against all, an eternal bellum omnium contra omnes, in comparison to which the old bellum omnium contra omnes and even the murderous natural condition of the state philosophy of Thomas Hobbes are true idylls." ${ }^{52}$ Schmitt's description of Weber's account of interminable value conflict resonates with the language of

\footnotetext{
${ }^{48}$ Schmitt, Die Tyrannei der Werte (1960), 5. Schmitt's direct target here is Max Scheler's work Der Formalismus in der Ethik und die materiale Wertethik.

${ }^{49}$ Ibid., 5 .

${ }^{50}$ Ibid., 5-6: "Bei Max Weber finden wir die klarsten und insofern auch ehrlichsten Antworten auf diese Frage. Danach ist es das menschliche Individuum, das in voller, rein subjektiver Entscheidungsfreiheit die Werte setzt. Auf diese Weise entgeht es der absoluten Wertfreiheit des wissenschaftlichen Positivismus und setzt ihm seine freie, das heißt: subjektive Weltanschauung entgegen."

${ }^{51}$ Ibid., 6 n. 2. On this point, Christoph Schönberger writes of Schmitt's pamphlet, "The title already contains the whole thesis. Values can offer the commonwealth and its law no fixed ground; they rather sharpen much more its problems. Precisely when one expects of them that they ought to found commonality, their effect is destructive." See Schönberger, "Werte als Gefahr für das Recht?," 57-91, at 57.

${ }^{52}$ Schmitt, Die Tyrannei der Werte (1960), 6: "Die rein subjektive Freiheit der Wertsetzung führt aber zu einem ewigen Kampf der Werte und der Weltanschauungen, einem Krieg Aller mit Allen, einem ewigen bellum omnium contra omnes, im Vergleich zu dem das alte bellum omnium contra omnes und sogar der mörderische Naturzustand der Staatsphilosophie des Thomas Hobbes wahre Idyllen sind."
} 
the Federal Constitutional Court in the Lüth judgment. Where the justices grounded their expansion of the basic rights into private law on the ground of an "order of values" (Wertordnung), Schmitt here deploys this very language to offer an image of ceaseless and exacerbated violent conflict-more violent indeed than the frightful depiction of the state of mere nature in chapter 13 of Thomas Hobbes's Leviathan. As in his earlier anonymous "Amnesty" op-ed, Schmitt emphasizes that the ability to call someone not convicted of crimes a "war criminal" or violator of human rights will serve only to exacerbate latent and open social conflicts.

Continuing his genealogy of value theory into twentieth-century philosophy, Schmitt presents Nicolai Hartmann and Max Scheler as having "attempted to avoid the subjectivism of valuations and to find an objective and material value philosophy." ${ }^{53}$ Depicting these attempts as unsuccessful, Schmitt writes that in pursuing this aim of objectivizing value,

Max Scheler erected a stadial order of values, which went from the bottom to the top, from useful to holy. Nicolai Hartmann constructed a system of the objective relation of a real world in layers, the lowest of which was to have been the anorganic, the highest of which was to have been the spiritual. But however high and holy certain values may be held, as values they only ever hold for something or for someone. ${ }^{54}$

Schmitt thus maintains that material and objective value theory fail in their attempts to remove the subjectivity of value discourse and the interminable conflict to which it seems to give rise. An objective order of values, on this account, is no less subjective for being labeled otherwise.

Schmitt's genealogy of value thinking in the history of nineteenth- and twentieth-century thought ends where it began, with the grammar of value discourse. Values are set and held-they don't exist apart from a valuing subject. "No one can escape the immanent logic of value-thinking," Schmitt holds;

Whether subjective or objective, ${ }^{[55]}$ formal or material, as soon as value appears, a specific thought circuit becomes unavoidable. It is-one must

\footnotetext{
${ }^{53}$ Ibid., 6. For an account of Schmitt's argument at this point in the pamphlet, Reinhard Mehring writes that Schmitt "then distinguishes Max Weber's subjective value theory from the objective value philosophies of Max Scheler and Nicolai Hartmann. At the level of the theory of validity he [Schmitt] agrees with Weber." Mehring, Aufstieg und Fall, 520.

${ }^{54}$ Schmitt, Die Tyrannei der Werte (1960), 6-7 (emphasis in the original). As Jan-Werner Müller emphasizes, Scheler and Hartmann were prominent sources for constitutional jurisprudence in the Federal Republic in the 1950s. "As a result of this rejection of positivism there was a brief flowering of natural law in legal thought, and, subsequently, a much more extended and philosophically complex search for secure foundations to fortify the liberal democratic order. In particular, the 'material value-philosophy' of Max Scheler and Nicolai Hartmann appeared as a non-religious alternative to natural law thinking. Such material, Christian-inspired conceptions had initially been behind the judgments of the Constitutional Court." Müller, A Dangerous Mind, 70. In thus undermining and critiquing Hartmann and Scheler, Schmitt is continuing his project of critiquing Federal Republican jurisprudence and the Lüth judgment in particular.

${ }^{55}$ Schmitt's phrase "or objective" (oder objektiv) is omitted from the 1979 edition, but it is present in the 1960 and 1967 editions and restored in the 2011 edition. The author reads its omission from the 1979
} 
already say: compulsorily_given with every value thinking. As that which is specific lies precisely therein, that instead of being it only has validity. The setting is consequently nothing, if it is not put through. ${ }^{56}$

Where in his Concept of the Political Schmitt had stressed that "whoever says humanity desires to deceive," ${ }^{, 57}$ in The Tyranny of Values Schmitt echoes his earlier claim with an appeal directed against the Lüth judgment, "Whoever says value, wants to make valid and impose values. Virtues one exercises; norms one applies; commands are fulfilled; but values are set down and imposed. Whoever asserts their validity must make them valid. Whoever says that they're valid without a human making them valid, desires to deceive." ${ }^{58}$ In sum, on Schmitt's account, as a matter of philosophic grammar, values aren't real; as a matter of philosophic history, values are ersatz metaphysics and stress subjective worldviews in a way that leads to interminable conflict and violence. All attempts to render values "objective," on Schmitt's narrative, expose themselves as little more than lending expression to a will to power.

Closing out his exordium in The Tyranny of Values, Schmitt notes that the distinctions of value theory are "capable of being linked up with a complex situation." 59 Schmitt's discursive situation in the 1960 privately printed pamphlet version of The Tyranny of Values shares certain surface or structural ambiguities with the speech situation of both Lüth and Harlan in the political circumstances leading up to the Lüth judgment. As was the situation for Lüth, it is potentially ambiguous whether Schmitt, in addressing the jurists assembled in Ebrach, is speaking wholly in his capacity as a private citizen or, rather more ceremoniously, as a former representative of the Nazi state addressing up-and-coming legal academics alongside older National Socialist jurists, at a postwar retreat especially for them. ${ }^{60}$ Schmitt regarded Veit Harlan, as his 1953 letter to Ernst Forsthoff makes clear, ${ }^{61}$ as the victim of "persecutions driven ever further" on account of Harlan's prior engagements on behalf of National Socialism. ${ }^{62}$ No less, Schmitt viewed himself as subject to similar mistreatment-under a university teaching

edition as a typographical error. Schmitt, Die Tyrannei der Werte (1960), 7; Schmitt, Die Tyrannei der Werte (1967), 55; Schmitt, Die Tyrannei der Werte (1979), 32; Schmitt, Die Tyrannei der Werte (2011), 41.

${ }^{56}$ Schmitt, Die Tyrannei der Werte (1960), 7.

${ }^{57}$ Carl Schmitt, The Concept of the Political, trans. George Schwab (Chicago, 1996), 54. Compare Schmitt, Dialogues, 29.

${ }^{58}$ Schmitt, Die Tyrannei der Werte (1960), 7.

${ }^{59}$ Ibid., 3.

${ }^{60}$ On the meetings and seminars at Ebrach see Dirk van Laak, Gespräche in der Sicherheit des Schweigens: Carl Schmitt in der politischen Geistesgeschichte der frühen Bundesrepublik (Berlin, 2002; first published 1993), 200-8.

${ }^{61}$ Letter of Carl Schmitt to Ernst Forsthoff dated 3 Sept. 1953, in Briefwechsel Ernst Forsthoff-Carl Schmitt, Letter 62, 97. This letter is cited, but not quoted, in Burkhardt, Carl Schmitt und die Öffentlichkeit, 28 n. 49.

${ }^{62}$ Letter of Carl Schmitt to Ernst Forsthoff dated 3 Sept. 1953, in Briefwechsel Ernst Forsthoff-Carl Schmitt, Letter 62, 97: "Nach den immer weiter betriebenen Verfolgungen und dem ungenierten Triumph privater Rachsucht und unlautersten Wettbewerbs, traf mich eine solche mutige Anerkennung so tief, dass sie mir das Bild von meinem Beruf und meinem Stande wieder erträglich gemacht hat." 
prohibition from the German state ${ }^{63}$ and subject to calls ranging from boycott to war crimes tribunals for his advocacy of Nazi foreign policy, racial discrimination against Jews, and defenses of German atrocities in the Shoah. ${ }^{64}$ Schmitt perceived himself, as he perceived Harlan, to be subject to persecution in the absence of a statutory violation which, in these instances, he held to be equivalent to the absence of crime. ${ }^{65}$

The private printing of the first edition of The Tyranny of Values may seem to play upon both ambiguities of this discursive situation. The text is at once not wholly public, as a Privatdruck distributed, in part, within the circles of Schmitt's former Nazi disciples, yet not wholly private, as it is written, expressed, spoken and printed to be circulated, disseminated and shared. The private printing of The Tyranny of Values may thus be read as a loose commentary on the status of prohibiting boycotts in private law in the aftermath of the Lüth case. Lüth's calls for the boycott of Harlan's postwar films threatened the commercial interests of Harlan's production company, which sued Lüth to prohibit the boycott, initially with success. Yet because Schmitt's pamphlet was circulated without the need to profit from booksales, calls to boycott Schmitt's Tyranny of Values might prove correspondingly ineffective. With more than a hint of dark humor, Schmitt thus winks away a potential call to boycott his text despite such a call's newly acquired status of constitutionally protected speech.

As The Tyranny of Values draws to a close, Schmitt concludes his polemic against the language of value with a reflection on the history of National

\footnotetext{
${ }^{63}$ On how the university teaching ban against Schmitt functioned in practice see Henning Ritter's memoir, Verehrte Denker: Porträts nach Begegnungen (Springe am Deister, 2012), 8: "Daß er in Münster auftreten konnte, ohne daß es seitens der Universität zu einem Einspruch kam, erklärt sich dadurch, daß diese Veranstaltung als private Begegnung deklariert wurde. Die Teilnahme war sogar für die Mitglieder des Collegiums freiwillig, und die Zuhörer brachten die gesamten Kosten des Besuchs von Carl Schmitt in Münster aus der eigenen Tasche auf"/“That he [Schmitt] could appear in Münster, without running into an objection on the side of the university, is explained by the fact that this event was declared to be a private gathering. The participation was even voluntary for the members of the Collegium [Philosophicum], and the auditors picked up the entire cost of the visit of Carl Schmitt in Münster out of their own pockets." On Ritter's presentation, Schmitt could still speak in university settings by invitation (by Joachim Ritter or Ernst-Wolfgang Böckenförde, for example) at events declared to be private, and student attendance at seminars and lectures at which Schmitt spoke was optional.

${ }^{64}$ See Carl Schmitt, "Eröffnung der wissenschaftlichen Vorträge durch den Reichsgruppenwalter Staatsrat Prof. Dr. Carl Schmitt," in Schmitt, Das Judentum in der Rechtswissenschaft: Ansprachen, Vorträge und Ergebnisse der Tagung der Reichsgruppe Hochschullehrer des NSRB. am 3. und 4. Oktober 1936, 1. Die deutsche Rechtswissenschaft im Kampf gegen den jüdischen Geist (Berlin, 1936), 14-17, at 14: "Der tiefste und letzte Sinn dieses Kampfes und damit auch unserer heutigen Arbeit aber liegt in dem Satz des Führers ausgesprochen: 'Indem ich mich des Juden erwehre, kämpfe ich für das Werk des Herrn"'/"The deepest and last sense of this battle and therewith also our contemporary work, however, lies in the articulated proposition of the Führer: 'Wherein I battle in resistance against the Jews, I fight for the work of the Lord.", cited in Zeitlin, "Interpretation and Critique," 26-7. See also Carl Schmitt, Land and Sea: A World-Historical Meditation, ed. Russell A. Berman and Samuel Garrett Zeitlin (Candor, NY, 2015), sections 1, 3, 17; and the discussion in Samuel Garrett Zeitlin, "Propaganda and Critique," in ibid., xlii-xlvi. See also Joshua Smeltzer, "'Germany's Salvation': Carl Schmitt's Teleological History of the Second Reich," History of European Ideas 44/5 (2018), 590-604.

${ }^{65}$ On this theme in Schmitt's postwar work see also Carl Schmitt, Das internationalrechtliche Verbrechen des Angriffskrieges und der Grundsatz "Nullum crimen, nulla poena sine lege", ed. Helmut Quaritsch (Berlin, 1994), trans. in Timothy Nunan, ed. Writings on War (Cambridge, 2011), 125-97.
} 
Socialism and works which were appropriated by National Socialism to the end of propagating atrocities. In the final section of the pamphlet Schmitt states that

\section{In the year 1920 there appeared in Germany a text, which bore an ominous} title: Freigabe der Vernichtung lebensunwerten Lebens [Permitting the Annihilation of Life Unworthy of Life $\left.{ }^{[66]}\right]$. Its authors were two highly regarded German scholars from the best tradition of German education, the medical doctor Alfred Hoche and the jurist Karl Binding. Both were liberal humans of their time, both ensouled with the best, humane intentions. Both have reflected in a really moving way on how one could hinder an abuse of their proposals for the annihilation of life not worthy of living via reservations and precautions of all kinds. It would be not only unjust, but also despicable, to attach to both German scholars any guilt or responsibility ex post ${ }^{[67]}$ for the terrifying practice of the annihilation of life unworthy of living, which became a reality twenty years later. ${ }^{68}$

Schmitt here generalizes his critique of post-Second World War trials of Nazi criminals emphasizing that "any guilt or responsibility ex post" would be "not only unjust, but also despicable." Moreover, Schmitt recapitulates his own Nazi convictions, in 1960, by redescribing the victims of the Shoah as suffering the fate of "the annihilation of life unworthy of living." 69 This claim may fairly be read as a continuing public print endorsement of the Shoah in the 1960s and 1970s by one of the leading lawyers of National Socialism. ${ }^{70}$ With this, Schmitt's polemical target in this pamphlet, pursued with indirection at several levels of remove, becomes

\footnotetext{
${ }^{66}$ Lit. "life without life-value."

${ }^{67}$ Latin in Schmitt's German original: after the fact. Italicized in the 1960 edition, and deitalicized in the 1967 edition (in which the entire 1960 text is placed in italics, removing internal typographic distinctions) and subsequent editions; the italics are here restored. Schmitt Die Tyrannei der Werte (1960), 15; Schmitt Die Tyrannei der Werte (1967), 61; Schmitt Die Tyrannei der Werte (1979), 39; Schmitt Die Tyrannei der Werte (2011), 52. An error in the 2018 English translation omits the phrase "to both German scholars" (den beiden deutschen Gelehrten). See Schmitt, The Tyranny of Values and Other Texts, 39.

${ }^{68}$ Schmitt, Die Tyrannei der Werte (1960), 14-15. Note that Schmitt here seems to redescribe the Shoah in the terms of the title of the book by Hoche and Binding. Schmitt's statement here is, at the very least, ambiguous. As the translator's notes to the 2018 English edition of the work observe, "Schmitt here seems to make reference to the Nazi euthanasia program of 1939, also known as the T4 Aktion, i.e. the murder of mentally and physically disabled Germans, whom the Nazis considered 'unworthy of life' ... another reading of this passage would be that Schmitt here may seem to redescribe the Shoah as a whole in the terms of the title of the book by Hoche and Binding." See Carl Schmitt, The Tyranny of Values and Other Texts, ed. Russell A. Berman and Samuel Garrett Zeitlin (Candor, NY, 2018), 39 n. 40.

${ }^{69}$ For an interpretation that Schmitt also held this position during the Second World War see Joshua Derman, "Carl Schmitt on Land and Sea," History of European Ideas 37/2 (2011), 181-9, at 189. On Schmitt's 1942 argument (reprinted in 1954 and 1981) that the Jewish people, in his view, fall outside the category of "the human" see Schmitt, Land and Sea, sections 3, 17; and Samuel Garrett Zeitlin, "Propaganda und Kritik: Eine Einführung in Carl Schmitts 'Land und Meer'," Politisches Denken. Jahrbuch 2017, Band 27, 115-43, at 122-4.

${ }^{70}$ Schmitt, Die Tyrannei der Werte (1960), 14-15. On this point compare William E. Scheuerman, Carl Schmitt: The End of Law (Lanham, 1999), 175: "Did Schmitt revise his views following Germany's military defeat in 1945? Probably not. The overwhelming tone of Schmitt's postwar writings is fundamentally unrepentant."
} 
frighteningly clear and explicitly direct: he aims to defend Harlan in the Lüth case, but also, more broadly, all those (like himself) who have been accused of war crimes, atrocities, crimes against the Jewish people and crimes against humanity for their actions on behalf of German National Socialism. Schmitt's pamphlet, The Tyranny of Values, and his anonymously circulated op-ed, "Amnesty and the Force of Forgetting," share a joint aim and a common polemical thrust: the defense and exculpation of Nazi war criminals against those who might ascribe to them "any guilt or responsibility ex post."

\section{Karl Löwith, the critique of tyranny, and Schmitt's riposte: the second edition of 1967}

Four years after the private printing of Schmitt's pamphlet and its circulation among his students and friends, The Tyranny of Values became an item of note and controversy spread across the broadsheet pages of the Frankfurter Allgemeine Zeitung. The philosopher Karl Löwith, who emigrated from Nazi Germany following forced removal from university employment under Nazi racial legislation, took to print to criticize Schmitt's pamphlet and the unrepentant National Socialism and persistent anti-Jewish racism of which Löwith considered Schmitt's work to be exemplary. ${ }^{71}$

The ostensible occasion of Löwith's article was the hundredth anniversary of Max Weber's birth in $1864 .{ }^{72}$ In the article "Max Weber and Carl Schmitt," Löwith wastes little time in offering the view that Max Weber is to be considered an intellectual trailblazer of Hitlerism-and this both positively and negatively. Though Weber died in 1920, Löwith stresses that in his estimation Weber "positively paved the way to the authoritarian and dictatorial Führer-state [Führerstaat] via his depictions of the irrationally 'charismatic' leadership [Führerschaft] and the 'mechanized-leader democracy' [Führerdemokratie mit Maschine] and negatively via the intentional contentlessness, via that which is formal in his political ethos, the last instance of which was only the decisive choice of one value imposition [Wertsetzung] amongst others, it didn't matter which one." ${ }^{\text {"3 }}$ While crediting Weber, long dead in 1933, with positively blazing the path for the "dictatorial Führerstaat" and negatively offering a formal political ethos that did nothing to stop it, Löwith's assessment of Carl Schmitt in this same article was less resonantly imbued with esteem. Schmitt, in Löwith's understanding, was to be seen as "the theoretician of the transition from the parliamentary democracy of the national-liberal party state to the authoritarian and dictatorial democracy of

\footnotetext{
${ }^{71}$ Karl Löwith, "Max Weber und Carl Schmitt," Frankfurter Allgemeine Zeitung, 27 June 1964; reprinted as Löwith, "Max Weber und Carl Schmitt (FAZ vom 27. Juni 1964)," Zeitschrift für Kulturphilosophie 2 (2007), 365-75. The original article occupies a single page of broadsheet in the Saturday edition of the Frankfurter Allgemeine Zeitung.

${ }^{72}$ Löwith's article opens with the italicized preface: “Der 100. Geburtstag Max Webers ist vorüber. Die Diskussion aber geht weiter. Sie spannt den Bogen in die Zeitgeschichte. Der Name Carl Schmitt ist in ihr aufgetaucht. Wie sehr die Parallelen täuschen, zeigt hier der Heidelberger Ordinarius für Philosophie Karl Löwith"/“The 100th birthday of Max Weber is past. The discussion, however, goes on. It spans the bow into contemporary history. The name of Carl Schmitt has shown up in it. How very much the parallels deceive, the Heidelberg Ordinarius [Professor] for Philosophy Karl Löwith shows here."

${ }^{73}$ Karl Löwith, "Max Weber und Carl Schmitt," 369.
} 
the total state." 74 In this last regard, Löwith added, Schmitt was indicative of the development of the German state and of German society itself. ${ }^{75}$

Here, Löwith emphasized especially Schmitt's proximity to Nazi racial discourse during the Third Reich and Schmitt's appropriation of the notion of racial "typological equality" (Gleichartigkeit), which was wielded by the Nazis to isolate and persecute Jews as persons who were racially "typologically foreign" (Artfremd). ${ }^{76}$ From noting Schmitt's deployment of Nazi racial ideology, Löwith turned sharply to Schmitt's Tyranny of Values. "From Weber's thesis of one's own decision for this or that final value," Löwith wrote citing the privately printed edition of The Tyranny of Values, "Schmitt has recently drawn the conclusion that this 'tyranny" of mutually conflicting, because mutually exclusive, 'values' would lead to a bellum omnium contra omnes, in comparison with which the murderous natural condition of the state philosophy of Thomas Hobbes is an idyll." ${ }^{77}$ In contrast to Weber's notion of responsibility, Löwith claimed, "Schmitt's dictatorial decisionism" amounts to a kind of occasionalism, not untinged with opportunism. Löwith thereby repeated his famous critique of Schmitt during the National Socialist era that Schmitt was an "occasional decisionist," 78 redeployed on the occasion of his reading of The Tyranny of Values, to the reading public of the Frankfurter Allgemeine Zeitung (FAZ).

Schmitt did not take kindly to Löwith's critique in the pages of the Frankfurter Allgemeine. His reply to Löwith took the form of an introduction to a public reprinting of his Tyranny pamphlet, this time in the 1967 Festschrift for his student Ernst Forsthoff, the former Nazi propagandist at whose seminar Schmitt delivered the original lecture version of what became The Tyranny of Values. Closing out this 1967 introduction to the Tyranny of Values, Schmitt took indirect aim at Löwith. Noting that his pamphlet had been published in Spanish translation in Franco's Spain and approvingly cited by Julien Freund in the latter's French translations of Max Weber's Wissenschaftslehre, Schmitt lamented, "In Germany, a peculiar fate befell the private printing." Without mentioning Löwith by name but citing precisely the issue number of the $F A Z$ in which Löwith's article appeared, Schmitt wrote of his privately printed pamphlet,

\footnotetext{
${ }^{74}$ Ibid., 370.

${ }^{75}$ Ibid., 370 .

${ }^{76}$ Ibid., 372: "Das geschieht seit der 3. Auflage des 'Begriffs des Politischen' im Anschluß an die antisemitische Rassenlehre, der er ursprünglich fern stand ... Zur Substanz des totalen Staates wird nun der 'artgleiche' Volksgenosse, der die demokratische Gleichartigkeit von Führer und Geführten verbürgen soll. Die biologische Gleichheit der Rasse ersetzt die theologische Gleichheit vor Gott und die moralische vor dem Gesetz"/"This occurs after the third edition of the 'Concept of the Political' in linking up with the anti-Semitic racial doctrine, which he originally stood far away from ... The substance of the total state now becomes the 'typologically equal [artgleiche]' folk-comrade, who ought to guarantee the democratic equality of type [Gleichartigkeit] of the leader [Führer] and the led. The biological equality of the race replaces the theological equality before God and the moral equality before the law."

${ }^{77}$ Ibid., 373. Löwith's reference to Schmitt's Tyranny is accompanied in both the original FAZ article and in the 2007 reprint with a starred footnote (following "neuerdings"), which reads "Die Tyrannei der Werte 1960 (Privatdruck), S. 6."

${ }^{78}$ See Karl Löwith, "The Occasional Decisionism of Carl Schmitt," in Löwith, Martin Heidegger and European Nihilism, ed. Richard Wolin, trans. Gary Steiner (New York, 1995), 137-69.
} 
After four years it was suddenly seized upon and drawn into a polemical confrontation via a world paper. ${ }^{[79]}$ That which was expressed within a circle of roughly 40 auditors and then as a private printing for at most 200 readers-always within the frame of a discussion about virtue and value in state theory-now saw itself in the loudspeaker cited before a forum of a wholly other kind [ein ganz anders geartetes Forum] of some hundreds of thousands of readers, without these readers receiving, even approximately, any information about the meaning and bearing of the discussion. ${ }^{80}$

Schmitt's use of ganz anders geartetes in this context is not wholly free of the connotations of this phrase in Nazi racial theory and Nazi law. Given that the author of the FAZ piece was Karl Löwith, a longtime critic of Schmitt who was forced into exile by Nazi racial laws, and given that the 1967 edition of Tyranny appeared in a Festschrift for a well-known Nazi lawyer and propagandist, this allusion may not be wholly unintentional on Schmitt's part. Schmitt uses the phrase at the end of his pamphlet Staat, Bewegung, Volk to refer to lawyers of Jewish ancestry and to advocate their political, professional and existential exclusion from the Gefolgschaft of Schmitt's Führer. ${ }^{81}$ In that Hitlerian work, published in successive editions in 1933, 1934 and 1935, Schmitt wrote of the Jews he wished to exclude from Hitlerian Germany, "One who is typologically foreign [Ein Artfremder] may gesture so critically and exert himself so sharply, may read books and write books, he thinks and understands otherwise, because he is typologically other [anders geartet ist] and remains in every decisive trajectory of thought within the existential conditions of his type." ${ }^{\prime 2}$ It is with homogeneity and typological equality (Artgleichheit) that the Schmitt of 1933-5 circumscribed the followership of his Führer and conceptually it was in exclusion of the typologically other (those who are anders geartet, in Schmitt's terms) that Schmitt excluded and persecuted Jews.

While Schmitt had no hesitation deploying the Nazi racial discourse of artgleich, andersartig, anders geartet, and artfremd in public and private to discriminatory and murderous ends during the Third Reich, as the historians Andreas Koenen, Ingo Müller, and Raphael Gross have amply shown, ${ }^{83} \mathrm{Schmitt}$ also had no qualms deploying this same vocabulary in public in the 1967 second edition of The

\footnotetext{
${ }^{79}$ The thirteenth note to Schmitt's 1967 text, and the fourteenth note to the 1979 and 2011 texts, read, "Frankfurter Allgemeine Zeitung, no. 146, June 27, 1964."

${ }^{80}$ Schmitt, Die Tyrannei der Werte (1967), 51; Schmitt, Die Tyrannei der Werte (2011), 33.

${ }^{81}$ Schmitt, Staat, Bewegung, Volk, Die Dreigliederung der politischen Einheit (Hamburg, 1933; subsequently published 1934, 1935), 32-46, esp. 42-45. See also Smeltzer, "Germany's Salvation," 601-2.

${ }^{82}$ Schmitt, Staat, Bewegung, Volk, 45: "Ein Artfremder mag sich noch so kritisch gebärden und noch so scharfsinnig bemühen, mag Bücher lesen und Bücher schreiben, er denkt und versteht anders, weil er anders geartet ist, und bleibt in jedem entscheidenden Gedankengang in den existentiellen Bedingungen seiner eigenen Art." Italics original in all three editions.

${ }^{83}$ On Schmitt's use of Nazi racial theory and language to persecute Jews under Nazism see Ingo Müller, Furchtbare Juristen: Die unbewältigte Vergangenheit der deutschen Justiz (Berlin, 2018; first published 1987), 55-60. See also Raphael Gross, Carl Schmitt und die Juden: Eine deutsche Rechtslehre, Durchgesehene und erweiterte Ausgabe (Frankfurt am Main, 2005; first published 2000). On the centrality of distinctions of type (Art) to Schmitt's deployment of Nazi racial theory to persecute Jews and bar them from professions in the 1933-6 period see Andreas Koenen, Der Fall Carl Schmitt: Sein Aufstieg zum "Kronjuristen des Dritten Reiches" (Darmstadt, 1995), 318, 423, 492, 728-30.
} 
Tyranny of Values. Schmitt's riposte to Löwith amounted to applying Nazi racial discourse of being ganz anders geartet (wholly typologically foreign) to both Löwith and the broader readership of the Frankfurter Allgemeine in the late 1960s. In the late 1960s, Carl Schmitt was redeploying thinly veiled Nazi racial discourse in public, precisely against those who had been its unfortunate victims under Nazism itself. In this regard, Schmitt's use of this language is the mannered or public face of what Schmitt privately professed in his diaries in the postwar period, in which Schmitt asserted that "Jews always remain Jews," adding to this Schmitt's view that "[p]recisely the assimilated Jew is the true enemy. There is no purpose at all in showing the speeches of the Elders of Zion to be false."

Beyond using the occasion of the reprinting of his pamphlet to insult Karl Löwith with Nazi racial discourse, Carl Schmitt saw fit to expand his pamphlet via this introduction with the aim of treating other themes. Not least, Schmitt used the 1967 introduction to The Tyranny of Values to give voice to his opinions on the Second Vatican Council. The "tyranny" of the language of value is present, Schmitt wrote, "in all domains of our social being" no less than it "documents itself even in the official language of the highest spheres." 85

For Schmitt, "the official language of the highest spheres" was the language of the Church. ${ }^{86}$ And Schmitt proceeded to cite what he took to be examples of the execrable language of value from examples drawn from the papal encyclicals and conciliar declarations of Vatican II. "This is shown," Schmitt wrote,

in the translations of the social encyclical of Pope John XXIII, Mater et Magistra of 15 May 1961. Here the Latin word Bonum ${ }^{87}$ (good) is rendered in the Italian translation with valore, in German with Wert (value). Often this linguistic transformation is justified with the claim that the Latin termini could no longer follow the tempo of the modern industrial technological development. In the declaration of the Second Vatican Council concerning the "Relation of the Church to Non-Christian Religions" ${ }^{88}$ on October 28, 1965, after the bona spiritualia et moralia, the valores socio-culturales are named-which can also be found among those who profess non-Christian religions —and ought to be recognized, defended, and advanced. ${ }^{89}$

\footnotetext{
${ }^{84}$ Schmitt's diary entry of 25 Sept. 1947 in Carl Schmitt, Glossarium: Aufzeichnungen der Jahre 19471951, ed. Eberhard Freiherr von Medem (Berlin, 1991), 18; Schmitt, Glossarium, Aufzeichnungen aus den Jahren 1947 bis 1958, 14. The author is grateful to an anonymous reader for Modern Intellectual History for drawing attention to these passages.

${ }^{85}$ Schmitt, Die Tyrannei der Werte (1967), 39; Schmitt, Die Tyrannei der Werte (1979), 13; Schmitt, Die Tyrannei der Werte (2011), 12.

${ }^{86}$ On this see Carl Schmitt, Römischer Katholizismus und politische Form, 5th edn (Stuttgart, 2008; first published 1923). In the final years of his life, Schmitt authorized the republication of this work in the Edition Maschke imprint of Hohenheim Verlag, a publisher of the German medical association, alongside republication of Schmitt's Hamlet oder Hekuba as well as the Nazi-era works Land und Meer and Der Leviathan, republished with Hohenheim Verlag in 1981 and 1982 respectively.

${ }^{87}$ Bonum ("good") is given in Latin and capitalized in Schmitt's German original.

${ }^{88}$ Nostra aetate.

${ }^{89}$ Schmitt, Die Tyrannei der Werte (1967), 39; Schmitt, Die Tyrannei der Werte (1979), 13-14; Schmitt, Die Tyrannei der Werte (2011), 12-13. On Schmitt's opposition to the Second Vatican Council see also Hohendahl, Perilous Futures, 151-9; 176-7.
} 
The language of value in these Vatican II encyclicals and conciliar declarations, Schmitt stressed, exhibit a "transformation in values, a general trans-valuation." What is most striking in Schmitt's examples is his choice of only the encyclical Mater et Magistra and the declaration Nostra aetate (on the relation of the Church to non-Christian religions) to illustrate the perfidiousness of the language of value. For these were precisely the documents of the Second Vatican Council which altered the Church's stance towards a greater tolerance of Islam and Muslims and of Judaism and Jews. It was precisely these encyclicals and declarations on which Schmitt expressed his public dubia of the Second Vatican Council.

Schmitt had not historically shown great sympathy towards a stance of toleration with regard to Judaism and Islam. ${ }^{91}$ As recently as 1950 in Der Nomos der Erde, Schmitt had emphasized that the Catholic Church had defined itself historically by positing Jews and Muslims as the hostes perpetui of the Church. ${ }^{92}$ For Schmitt, relations of enmity are definitive for one's own self-understanding. ${ }^{93}$ On this view, a person or institution defines itself not least in defining itself against an explicit, public enemy. In renouncing one's explicit and public enemies, on this view, one ceases to be what one is. On Schmitt's view, in renouncing Jews and Muslims as hostes perpetui in Mater et Magistra and Nostra Aetate, the Catholic Church relinquished its historical identity and, in a certain sense, dissolved itself. Schmitt's opposition to Vatican II was thus not grounded upon a nostalgia-infused elegy for the Latin Mass. Rather, Schmitt's critique of Vatican II was leveled precisely against those papal encyclicals and decretals that withdrew the Church from its historic relation of "perpetual enmity" toward Muslims and Jews.

In 1979, Carl Schmitt's The Tyranny of Values found republication in the form of a debate with Lutheran theologians and publicists, printed by the Lutheran Publishing House (Lutherisches Verlagshaus) in Hamburg. ${ }^{94}$ In that later version, both Schmitt's earlier defense of Harlan and his later polemics against Löwith and the Second Vatican Council were reprinted, with some typographical errors, yet in substance and textual argument unaltered. In all the editions of The Tyranny of Values, Schmitt opts for his favored rhetorical strategy, the wielding of the weapons and testimony of one's opponent against those opponents themselves. In redescribing value philosophy

\footnotetext{
${ }^{90}$ Schmitt, Die Tyrannei der Werte (1967), 39; Schmitt, Die Tyrannei der Werte (1979), 13; Schmitt, Die Tyrannei der Werte (2011), 12.

${ }^{91}$ On Schmitt's utterances on Judaism and Islam during and after the Second World War see Zeitlin, "Propaganda and Critique," liii-lxi.

${ }^{92}$ Carl Schmitt, Der Nomos der Erde im Völkerrecht des Jus Publicum Europaeum (Cologne, 1950), 90: "Von der Kirche autorisierte Kreuzzüge und Missionskriege waren ohne Unterschied von Angriff oder Verteidigung eo ipso gerechte Kriege; Fürsten und Völker, die sich der Autorität der Kirche hartnäckig entzogen, wie Juden und Sarazenen, waren eo ipso hostes perpetui." Ibid., 73-4: "Der Krieg gegen Nichtchristen ist für ihn etwas anderes als der Krieg zwischen Christen. Alle christliche Theologen wußten, daß auch die Ungläubigen, die Sarazenen und die Juden Menschen sind, und doch beruhte das Völkerrecht der Respublica Christiana, mit seinen tiefen Unterscheidungen verschiedener Arten des Feindes und infolgedessen auch des Krieges, auf tiefen Unterscheidungen zwischen den Menschen und auf einer großen Verschiedenheit ihres Status."

${ }^{93}$ On the relation between Schmitt's view of enmity and self-understanding see Heinrich Meier, Die Lehre Carl Schmitts (Stuttgart, 2009; first published 1994).

${ }^{94}$ Carl Schmitt, Eberhard Jüngel and Sepp Schelz, Die Tyrannei der Werte, ed. Sepp Schelz (Hamburg: Lutherisches Verlagshaus Hamburg, 1979). See also Specter, Habermas, 73-6, 80-84, 196, 204.
} 
itself as tyrannical, Schmitt is well known to be appropriating the language of Hartmann, the language of value theory, against that theory itself. ${ }^{95}$ Yet, in so doing, Schmitt is also applying the language of tyranny to those powers that wield the language of value to their own ends. Schmitt, who refrained from applying the language of tyranny to the tyrant under whom he lived, applies the term "tyranny" to the jurisprudence of the Federal Constitutional Court, the German Federal Republic more broadly, and the American and British occupying forces in postwar Germany, whose puppets he took the Federal Republic and its institutions to be. ${ }^{96}$ If the old adage holds that under a tyrant one can only call the tyrant a prince, yet while under a republic or when speaking of republics one can call out a tyrant unabashedly, Schmitt may be seen to unintentionally validate this adage. For Schmitt, it is the republics that are tyrannical whilst he praises his tyrants as nothing less than divine. ${ }^{97}$

\section{Conclusion}

A close historical engagement with Carl Schmitt's The Tyranny of Values shows us something not only about Schmitt's thought, but also about the rhetoric and cast of

\footnotetext{
${ }^{95}$ G. L. Ulmen, Politischer Mehrwert: Eine Studie über Max Weber und Carl Schmitt, trans. Ursula Ludz (Weinheim, VCH, 1991), 259-90; 289: "Schmitt begriff sehr wohl, daß die 'Tyrannei der Werte' sich aus dem Wertdenken ergibt."

${ }^{96}$ Schmitt's assertion in Staat, Bewegung, Volk (1933-5) that his Führer is not a tyrant is bound up with Schmitt's racialist notion of Artgleichheit: "Nur die Artgleichheit kann es verhindern, daß die Macht des Führers Tyrannei und Willkür wird; nur sie begründet den Unterschied von jeder noch so intelligenten oder noch so vorteilhaften Herrschaft eines fremdgearteten Willens"/"Only the Artgleichheit [racial typological equality] can hinder the power of the Führer from becoming tyranny and arbitrary will; only it grounds the distinction with some yet so intelligent or yet so advantageous rule by a typologically foreign [fremdgearteten] will." Schmitt, Staat, Bewegung, Volk, 42. Compare Burkhardt, "Einführung," 29: "Von den vier Staatsformen, die Schmitt miterlebte, stand er der Bundesrepublik mit der größten Reserviertheit gegenüber"/ "Of the four state-forms which Schmitt experienced, he stood with the greatest reservedness towards the Federal Republic." That is, according to Burkhardt, Schmitt was more dubious toward the Federal Republic as a regime than he was toward either Hitler's Germany or the Kaiserreich.

${ }^{97}$ See Carl Schmitt, Dialogue on Power and Access to the Holder of Power (1954) in Schmitt, Dialogues, 23-50, at 41-2: "C.S. He who believes in an omnipotent and beneficient God cannot explain power as evil, nor can he explain it as neutral. The Apostle of Christianity, Saint Paul, says famously in the Letter to the Romans: All power is from God. The Pope Saint Gregory the Great, the exemplar of a papal shepherd of the people, expresses himself concerning this matter with the greatest clarity and decisiveness. Listen for once to what he says: God is the highest power and the highest being. All power is from him and is and remains in its essence divine and good. Should the devil have power, then even this power, in so far as it is power, is divine and good. Only the will of the devil is evil. But despite this ever evil, devilish will, power in itself remains divine and good. Thus speaks the great Saint Gregory. He says: Only the will to power is evil, but power itself is always good ... [C.S.:] all three in my view, Jacob Burckhardt and both Schlossers taken together, fail to even approximate Gregory the Great," italics in the original. As the scope of Schmitt's claim for the divinity of power, advanced through Paul and Gregory as his spokesmen and authorities, is temporally unlimited, Schmitt appears, in his Dialogue on Power and Access to the Holder of Power, to be advancing a claim for not only the legality but also the divinity of Hitlerian power, precisely in the aftermath of the Second World War. From Schmitt's assertion, "All power is from God," one should pose the question of what, in Schmitt's opinion, this entails for Schmitt's view of Hitlerian power. That this question is not posed frequently enough in anglophone Schmitt studies is a sign of the latter's persistent deficiencies. In his preface to the 1962 Spanish version of this text, published in Franco's Spain, Schmitt notes, "In our dialogue the term 'demonic' [demoníaco], so much in fashion in modern dissertations on power, does not appear." Schmitt, Dialogues, 20. For the interpretation that Schmitt ascribes to the position of those who "believe in an omnipotent and beneficent God" see Meier, Die Lehre Carl Schmitts, chap. 3.
} 
Nazi polemic in German public and semi-public discourse after 1945. In the aftermath of the Second World War, Schmitt advocated wholesale amnesty for all Nazi war criminals in a series of anonymous op-eds and newspaper articles, a set of writings which find their theoretical equivalent in The Tyranny of Values. Moreover, this work displays Schmitt's repeated use of the phraseology of Nazi racial theory to attack his critics of Jewish origin, repeated in print in the 1960s and 1970s. Schmitt's post-Second World War racism loses none of its venom for being mannered racism and for expressing itself in phraseology that is easily overlooked, just as his apologetics for the Shoah and for Nazi war criminals lose nothing in bile from their anonymous and indirect articulation. In this regard, Schmitt's Tyranny is a window into a chapter of the history of Nazism in the aftermath of the Second World War that still remains to be written.

Acknowledgments. For helpful comments on earlier versions of the present article, the author is thankful to Nicholas Baer, Russell Berman, Greg Conti, Jeremy Dell, Stefan Eich, Kinch Hoekstra, Adeel Hussain, Sarah Johnson, Duncan Kelly, Adam Lebovitz, Timothy Luke, Victoria Kahn, Clara Maier, John P. McCormick, Svetozar Minkov, David Pan, Lucia Rubinelli, Martin Ruehl, Luna Sabastian, Joshua Smeltzer, Blake Smith, Daniel Steinmetz-Jenkins, Matthew Specter, Shannon Stimson, Nathan Tarcov, Lars Vinx, Joanna Williamson, the anonymous reviewer for Telos Press and the four anonymous reviewers for Modern Intellectual History. The author is particularly grateful to Duncan Kelly and the editors of Modern Intellectual History for their patience and intellectual generosity. An earlier version of this article was intended as the first half of the introduction to Carl Schmitt, The Tyranny of Values and Other Texts, ed. Russell A. Berman and Samuel Garrett Zeitlin (Candor, NY: Telos Press Publishing, 2018).

Cite this article: Zeitlin SG (2021). Indirection and the Rhetoric of Tyranny: Carl Schmitt's The Tyranny of Values 1960-1967. Modern Intellectual History 18, 427-450. https://doi.org/10.1017/S1479244319000398 